Soil Science and Agricultural Engineering

http:/www.journals.zu.edu.eg/journalDisplay.aspx?Journalld=1\&queryType=Master

\title{
CHARACTERIZATIONS OF SOME ORGANIC MATERIALS SOURCES AND ANALYSIS OF THE HUMIC ACIDS EXTRACTED FROM THEM
}

\author{
Marwa I.M. Ibrahim ${ }^{* 1}$, E.A.M. Awad ${ }^{2}$, S.M.M. Dahdouh ${ }^{2}$, Wafaa M.T. El- Etr ${ }^{1}$ and \\ A.S.M. Ibrahim ${ }^{2}$ \\ 1. Soils, Water and Environ. Res. Inst. Agric. Res. Cent. (ARC), Egypt \\ 2. Soil Sci. Dept., Fac. Agric., Zagazig Univ., Egypt
}

Received: 18/03/2019; Accepted: 14/04/2019

\begin{abstract}
Different organic materials such as town refuse, compost, sewage sludge and biogas have been used as sources of humic acids (HA). However, a systematic characterization of these organic materials and their comparison of humic acids which extracted from them have not been reported. This is essential to decide the relative merits and demerits of these substances as sources of humic acids. The objective of this work was to extract and characterize the chemical compositions of the different four organic materials and humic acids which extracted from them. Results showed that the four organic materials which used in this study were, generally, different in all studied properties. Sewage sludge sample recorded high values of moisture content, saturation percent, cation exchange capacity, organic carbon and organic matter content and lower values in each of bulk density, $\mathrm{pH}$ and EC as compared to other organic samples. Also, the highest value for each of total and available nitrogen $\left(\mathrm{NH}_{4}{ }^{+}\right.$and $\left.\mathrm{NO}_{3}{ }^{-}\right)$was shown with sewage sludge and town refuse, respectively, while total and available phosphorus and potassium along with $\mathrm{C} / \mathrm{N}$ ratio were recorded with compost sample. Furthermore, the four organic materials were different in total micronutrients and heavy metals. The highest value for each of $\mathrm{Fe}, \mathrm{Co}$ and $\mathrm{Ni}$ was recorded with compost sample as well as similar results of $\mathrm{Pb}, \mathrm{Zn}$ and $\mathrm{Cu}$ were observed with sewage sludge sample. Moreover, elementary composition of humic acids extracted from different samples was rich in carbon, nitrogen and oxygen and poor in sulfur except for sewage sludge sample. The $\mathrm{C} / \mathrm{N}$ ratio was relatively high in $\mathrm{HA}$ extracted from biogas as well as $\mathrm{HA}$ from compost was superior in $\mathrm{C} / \mathrm{H}, \mathrm{O} / \mathrm{H}, \mathrm{N}+\mathrm{O} / \mathrm{C}$ and $\mathrm{E} 4 / \mathrm{E} 6$ values. The lowest value of $\mathrm{N} / \mathrm{H}$ was observed in $\mathrm{HA}$ extracted from biogas. On the other hand, obtained results reported that HA percentage was relatively high in biogas sample and the four organic materials can be arranged as following biogas $>$ town refuse $>$ compost $>$ sewage sludge. Also, total acidity of humic acid samples reveals that, HA of sewage sludge was superior as compared to the other organic materials. The highest value for each of total carboxyl groups and carboxyl/phenol ratio was found with HA extracted from town refuse sample, whereas the greatest value of total phenolic groups was recorded with HA derived from sewage sludge. Furthermore, Infrared spectral (IR) analysis provides further useful information concerning the molecular structures and characteristic bonds and scanning electron microscopy (SEM) showed some crystal forms found in all HA samples. These results elucidated that the chemical composition and the molecular structure of HA samples varies as per the origin and environment where decomposition has occurred. Present study also documented that the spectroscopic and imaging techniques can be successfully used to bring out the finer differences among HA extracted from different organic sources.
\end{abstract}

Key words: Organic materials, town refuse, compost, sewage sludge and biogas, humic acids, infrared spectrophotometer IR, scanning electron microscopy SEM.

\footnotetext{
Corresponding author: Tel. : +201007246687

E-mail address: merofas2008@yahoo.com
} 
686

\section{INTRODUCTION}

Organic materials must be characterized in order to predict and understand its behavior and chemistry. Numerous studies have been attempted to make out its structure and chemical composition; however, due to heterogeneity of samples, there is no definitive structure for organic matter although many structural models have been proposed (Meinelt et al., 2004). Organic materials i.e., town refuse, compost, sewage sludge and biogas have been used as sources of humic acids (HA). It is obligatory to know the chemical composition of each for further use as sources of humic acids. A humic substance is an end product of degraded materials that consists of transformed degradable compounds and dead microorganism tissues (Davies and Ghabbour, 1999). Recently, the extensions of sustainable agriculture and established organic farm have led to increasing applications of humic acids as source of organic fertilizer. Increase in the organic content of soils improves aeration, soil structure, increase the water holding capacity of the soil (Mangricha et al., 2000).

Also, various studies about the characterization of HA extracted from different organic materials (town refuse, compost, sewage sludge and biogas) have been carried out. Most of the work reported is about the content of organic elements $(\mathrm{C}, \mathrm{O}, \mathrm{N}, \mathrm{H})$ and E4/E6 (degree of aromaticity) of HA from particular source. Few of them have also reported some inorganic elements such as $\mathrm{S}$ and $\mathrm{P}$ present in HA (Baddi et al., 2003). On this background, an objective study was planned to characterize humic acids from various sources using chemical analysis. This included automatic analyzer, Fourier transforms infrared spectroscopy (FTIR) and scanning electron microscopy (SEM).

\section{MATERIALS AND METHODS}

The purpose of the present work was to evaluate some chemical properties of different organic materials along with extraction of humic acids from different sources. Chemical analyses of various humic acids sources were taken in consideration.

\section{Organic Material Samples Collection}

Four organic material samples were chosen for this work .Town refuses was collected from Al-Ghar station for assembling urban wastes,
Zagazig city and removes of any metals or harmful substances then cut and encircled to become compost. Compost was obtained from Al-Arabia factory for organic compost, ElKhttara, Sharkia Governorate, Egypt. Rice straw and animal residues were mixed and subject to suitable heat and moisture to complete the decomposition processes and to obtain mature compost with good qualities. Sewage sludge was collected from station of sewage effluents remediation, Zagazig City. Biogas manure was taken from Recycling of Agric. Residues Training Center Moshtohor, Qalyubia Governorate, Egypt. Biogas manure was manufactured by drying the anaerobic cow dung effluent. Fresh cow dung was fermented in a biogas digester at retention time of 45-50 days.

\section{Organic Material Analyses}

Four studied samples were analyzed for physical and chemical characteristics. The physical analyses included moisture content as described by (Page et al. 1982) and bulk density according to (Vomocil, 1965). Chemical analyses included $\mathrm{pH}$ and Electrical conductivity (EC) (Richards, 1954), cation exchange capacity (CEC) (Page et al., 1982). Organic carbon (OC) and organic matter (OM) (Jackson, 1973). Total macronutrients (N, P and $\mathrm{K}$ ), micronutrients ( $\mathrm{Fe}, \mathrm{Mn}, \mathrm{Zn}$ and $\mathrm{Cu}$ ) and heavy metals $(\mathrm{Pb}, \mathrm{Cd}, \mathrm{Co}$ and $\mathrm{Ni})$ were digested and measured as described by (Page et al., 1982). Available macronutrients $\left(\mathrm{NH}_{4}\right.$ and $\mathrm{NO}_{3}$ ), $\mathrm{P}$ and $\mathrm{K}$ were measured according to (Cottenie et al., 1982).

\section{Extraction and Purification of Humic Acids}

Humic substances from different organic materials were extracted by using $0.5 \mathrm{~N} \mathrm{NaOH}$ as described by (Schnitzer and Skinner, 1968). Dry organic materials $(50 \mathrm{~g})$ and $500 \mathrm{ml}$ of $\mathrm{NaOH}$ solution was shaken $120 \mathrm{rpm}$ under $\mathrm{N}_{2}$ gas atmosphere in sealed bottles for 24 hours, then centrifuged for 15 minutes at $6000 \mathrm{rpm}$ and the supernatant was removed then $\mathrm{pH}$ was adjusted to 2.0 by addition of $2 \mathrm{~N} \mathrm{HCL}$ and left overnight. The resulting brown precipitate was separated from the liquid phase by centrifugation $(1500 \mathrm{~g}, 30 \mathrm{~min}$.), the precipitate was freeze-dried for storage (unpurified humic acids).To purified dry humic acids, $(2 \mathrm{~g})$ was treated with $100 \mathrm{ml}$ from $0.5 \% \mathrm{HCI}-\mathrm{HF}$ solution $(5 \mathrm{ml} \mathrm{HCI}$ and $5 \mathrm{ml}$ $\left.\mathrm{HF} \mathrm{L}^{-1}\right)$, three times at room temperature according to (Schnitzer and Khan, 1972 and 1978). 


\section{Characteristics of Extracted Humic Acids}

Elemental analyses for carbon, hydrogen, nitrogen and sulfur contents of the purified humic acids were performed by Antomatic analyzer CHNS (Vario el 111 elementer). Oxygen was calculated by subtracting total amount of carbon (\%), hydrogen (\%), nitrogen (\%) and sulfur (\%) from 100 (Schnitzer, 1975). Total acidity of humic acids was determined according to method described by (Wright and Schnitzer, 1959). Carboxyl groups of humic acids were, also, determined by calcium acetate $\mathrm{Ca}(\mathrm{OAc})_{2}$ method according to Wright and Schnitzer (1959). Phenolic OH groups were determined in humic acids samples by subtracting $\mathrm{COOH}$ group's content from total acidity according to Kononova (1966). $\mathrm{E}_{4} / \mathrm{E}_{6}$ ratio in humic acid samples was measured by absorption at 465 and $665 \mathrm{~nm}$ acorroding to Schnitzer and Khan (1978).

\section{Infrared Spectrophotometer}

An infrared spectrum (IR) of humic acids was performed with Backman-IR 250 double beam grading spectrophotometer. Scanning was done from 500 to $4000 \mathrm{~cm}^{-1}$. The dried sample was prepared for infrared spectra using $\mathrm{KBr}$ pellets technique as described by Schnitzer (1977).

\section{Scanning Electron Microscopy (SEM)}

The surface morphology of the powdered humic acid samples was observed using scanning electron microscopy (SEM) technique.

\section{RESULTS AND DISCUSSION}

Organic materials pass too many stages through decomposition bio-oxidative process involved the mineralization and partial humification which leading to an establishment of a final product with certain humic properties (Zucconi and De Bertoldi, 1987).

\section{Characteristics of Organic Materials Samples}

Results presented in Table 1 show the physical and chemical properties of the organic material samples under study. The highest values for each of moisture (48.1\%) and saturation percent SP (180) was observed with sewage sludge samples, while the lowest one for each of moisture $(9.17 \%)$ and SP (93\%) was recorded with biogas manure and compost, respectively. The bulk density for all organic material sources were ranged between 0.42 and $0.87 \mathrm{Mg} \mathrm{m}^{-3}$. These results are in agreement with those obtained by Huerta-Pujol et al. (2010)

With respect to chemical properties $(\mathrm{pH}, \mathrm{EC}$, $\mathrm{CEC}, \mathrm{OC} \%$ and $\mathrm{OM} \%$ ) of studied organic materials, results in Table 1 show that the lowest value for each of $\mathrm{pH}$ and $\mathrm{EC}$ was recorded with sewage sludge sample, while the highest one were observed with compost sample. The optimum EC value was mentioned by Sefidkar et al. (2013). Also, results of cation exchange capacity (CEC) revealed that the greatest value (63.2 cmolc $\left.\mathrm{Kg}^{-1}\right)$ was observed with sewage sludge sample, while the least one $(35.2 \mathrm{cmolc}$ $\left.\mathrm{Kg}^{-1}\right)$ was found with town refuse. The highest value for each of organic carbon $\left(265 \mathrm{~g} \mathrm{Kg}^{-1}\right)$ and organic matter $\left(457 \mathrm{~g} \mathrm{Kg}^{-1}\right)$ was recorded with sewage sludge sample as compared to other samples. From the above mentioned results, it may be worth to mention that values of both compost and biogas manure were very close. Also, the organic matter in most of the organic materials under study exceeded $200 \mathrm{~g} \mathrm{Kg}^{-1}$ as a minimum limit stated by Ge et al. (2006). These results are in agreement with those obtained by Sadeghi et al. (2015) for mature compost.

With respect to total macronutrients content in organic materials, results in Table 1 show that sewage sludge sample was superior in total nitrogen (32.2 $\left.\mathrm{g} \mathrm{Kg}^{-1}\right)$, while compost was superior in total $\mathrm{P}\left(6 \mathrm{~g} \mathrm{Kg}^{-1}\right)$ and $\mathrm{K}\left(17.2 \mathrm{~g} \mathrm{Kg}^{1}\right)$. Such results are in agreement with those obtained by Zhang et al. (2009a).

Also, The $\mathrm{C}: \mathrm{N}$ ratio for all organic material sources ranged between 8.22:1 and 18.7:1 resembling the optimum (less than 25:1) for the mature compost as stated by Fathi et al. (2014). The highest $\mathrm{C}$ : $\mathrm{N}$ ratio was observed with compost sample, while the lowest one was found with sewage sludge.

Moreover, macronutrient availability reveal that both available ammonium and nitrate in town refuse sample were noted higher values (923 and $308 \mathrm{mg} \mathrm{Kg}^{-1}$, respectively) as compared to other organic materials samples. This view point is in agreement with (Siuris, 2011). Biogas 
Table 1. Physical and chemical analyses of investigated organic materials

\begin{tabular}{|c|c|c|c|c|}
\hline \multirow[t]{2}{*}{ Parameter } & \multicolumn{4}{|c|}{ Organic source } \\
\hline & Town refuse & Compost & Sewage sludge & Biogas manure \\
\hline Moisture (\%) & 13.1 & 10.4 & 48.1 & 9.17 \\
\hline Saturation Percent (SP) & 98.0 & 93.0 & 180 & 165 \\
\hline Bulk density $\left(\mathrm{Mg} \mathrm{m}^{-3}\right)$ & 0.87 & 0.80 & 0.42 & 0.62 \\
\hline pH (1:10) & 6.77 & 7.61 & 6.36 & 7.59 \\
\hline EC (1:10) & 5.54 & 6.20 & 4.00 & 4.01 \\
\hline $\operatorname{CEC~}\left(\mathrm{cmolc} \mathrm{Kg}^{-1}\right)$ & 35.2 & 50.5 & 63.2 & 52.8 \\
\hline $\mathrm{OC}, \mathrm{g} \mathrm{Kg}^{-1}$ & 164 & 205 & 265 & 218 \\
\hline OM, $\mathbf{g ~ K g}^{-1}$ & 282 & 353 & 457 & 375 \\
\hline \multicolumn{5}{|c|}{ Total macronutrients, $\mathrm{g} \mathrm{Kg}^{-1}$} \\
\hline $\mathbf{N}$ & 15.1 & 11.0 & 32.2 & 15.0 \\
\hline $\mathbf{P}$ & 0.50 & 6.00 & 3.40 & 1.60 \\
\hline $\mathbf{K}$ & 5.30 & 17.2 & 1.70 & 6.10 \\
\hline $\mathrm{C} / \mathrm{N}$ ratio & $10.9: 1$ & $18.7: 1$ & $8.22: 1$ & $14.5: 1$ \\
\hline \multicolumn{5}{|c|}{ Available macronutrients, $\mathrm{mg} \mathrm{kg}^{-1}$} \\
\hline $\mathbf{N H}_{4}-\mathbf{N}$ & 923 & 301 & 648 & 283 \\
\hline $\mathrm{NO}_{3}-\mathrm{N}$ & 308 & 104 & 248 & 104 \\
\hline $\mathbf{P}$ & 311 & 626 & 142 & 485 \\
\hline $\mathbf{K}$ & 748 & 1365 & 109 & 763 \\
\hline \multicolumn{5}{|c|}{ Total micronutrients, $\mathrm{mg} \mathrm{kg}^{-1}$} \\
\hline $\mathbf{F e}$ & 3043 & 3715 & 3138 & 3135 \\
\hline Mn & 162 & 487 & 190 & 547 \\
\hline $\mathbf{Z n}$ & 192 & 124 & 294 & 133 \\
\hline $\mathbf{C u}$ & 54.3 & 32.9 & 149 & 22.9 \\
\hline \multicolumn{5}{|c|}{ Total heavy metals, $\mathrm{mg} \mathrm{kg}^{-1}$} \\
\hline $\mathbf{P b}$ & 13.7 & 16.5 & 29 & 0.0 \\
\hline Cd & 11 & 8.5 & 9 & 2 \\
\hline Co & 19 & 27 & 16.5 & 6 \\
\hline $\mathbf{N i}$ & 38 & 52 & 48 & 23 \\
\hline
\end{tabular}


manure was recorded least values for ammonium and nitrates (283 and $104 \mathrm{mg} \mathrm{Kg}^{-1}$, respectively) as well as compost sample was recorded similar value for nitrate. The highest value for each of phosphorus and potassium available was observed with compost sample, while the lowest one for each of both available $\mathrm{P}$ and $\mathrm{K}$ was obtained with sewage sludge sample.

It is worthy to notice that the total micronutrients $(\mathrm{Fe}, \mathrm{Mn}, \mathrm{Zn}$ and $\mathrm{Cu}$ ) in organic material samples were different depending on the organic source. Total $\mathrm{Fe}$ ranged between 3043 and $3715 \mathrm{mg}$ $\mathrm{Kg}^{-1}$. The greatest value of total $\mathrm{Fe}$ was observed with compost sample, while the lowest one was obtained with town refuse. Total Mn ranged between 162 and $547 \mathrm{mg} \mathrm{Kg}^{-1}$. The highest value of total $\mathrm{Mn}$ was recorded with biogas manure, while the lowest one was found with town refuse. Moreover, sewage sludge sample was recorded high level of both total $\mathrm{Zn}$ and $\mathrm{Cu}$ (294 and $149 \mathrm{mg} \mathrm{Kg}^{-1}$, respectively), while the lowest value for each of total $\mathrm{Zn}$ and $\mathrm{Cu}$ was observed with compost and biogas samples, respectively. Similar results were observed by (Pawlowski et al., 2013).

In addition, the levels of total heavy metals $(\mathrm{Pb}, \mathrm{Cd}, \mathrm{Co}$ and $\mathrm{Ni})$ in Table 1 were varying according to the type of organic material. The total content of heavy metals ranges between $\left(0\right.$ and $\left.29 \mathrm{mg} \mathrm{kg}^{-1}\right)$ for $\mathrm{Pb},\left(2\right.$ and $\left.11 \mathrm{mg} \mathrm{kg}^{-1}\right)$ for $\mathrm{Cd},\left(6\right.$ and $\left.27 \mathrm{mg} \mathrm{kg}^{-1}\right)$ for Co and (23 and 52 $\mathrm{mg} \mathrm{kg}{ }^{-1}$ ) for Ni. The lowest contents of heavy metals $(\mathrm{Pb}, \mathrm{Cd}, \mathrm{Co}$ and $\mathrm{Ni})$ were found with the biogas sample, while the greatest ones of $\mathrm{Pb}$ and Cd were observed with sewage sludge and town refuse, respectively, whereas the greatest ones of $\mathrm{Co}$ and $\mathrm{Ni}$ were recorded with compost sample. These results were in harmony with those reported by Hernández et al. (2017).

\section{Properties of Humic Acids Extracted from Different Organic Materials}

The elemental composition of humic acids extracted depended upon the type of the organic material. Carbon is the major element in organic structures; it is metabolized initially in the form of carbon dioxide and converted to organic carbon mainly through the photosynthetic activities of higher plants and to a lesser extent by microorganisms. About $90 \%$ of the dry matter of plants is composed of carbonyl levels of varying complexities. Total carbon content of humic acids in Table 2 ranged between 497 and $541 \mathrm{~g} \mathrm{Kg}^{-1}$. The highest content was found with sewage sludge sample and the lowest one was observed with compost sample. These results are in agreement with those obtained by Allam (2005). Also, total nitrogen content in humic acids varies according to the kind of organic material. Sewage sludge was superior for total nitrogen content $\left(68.1 \mathrm{~g} \mathrm{Kg}^{-1}\right)$ followed by total $\mathrm{N}$ content $\left(67.5 \mathrm{~g} \mathrm{Kg}^{-1}\right)$ in town refuse sample, while the biogas sample was contained the lowest one $\left(38 \mathrm{~g} \mathrm{Kg}^{-1}\right)$. These results are in agreement with those obtained by El-Ghozoli (1998). Results in Table 2 show that the highest $\mathrm{C} / \mathrm{N}$ ratio (14.1) of humic acid was observed with biogas sample, while the lowest one (7.87) was recorded with town refuse. These results are in agreement with that obtained by El-Ghozoli (1994) who found that $\mathrm{C} / \mathrm{N}$ ratio of the studied humic acids differed according to the nature of organic residues.

\section{Hydrogen Content and C/H Ratio}

Results in Table 2 show that hydrogen contents ranged between 50.3 and $66 \mathrm{~g} \mathrm{Kg}^{-1}$ in the humic acid which extracted from different organic materials. The highest content of hydrogen $(\mathrm{H})$ in humic acid was $66 \mathrm{~g} \mathrm{Kg}^{-1}$ in town refuse sample followed by $63.3 \mathrm{~g} \mathrm{Kg}^{-1}$ in sewage sludge sample as compared to the other organic samples. The variations among the $\mathrm{C} / \mathrm{H}$ ratios of humic acids extracted from the different organic sources are relatively small, ranging between 8.05 and 9.88. However, ElGhozoli (1998) found that the contents of hydrogen in isolated HA from different organic residues were relatively smaller. The obtained results are in accordance with those obtained by Allam (2005). Last studies noticed that the hydrogen content of some humic acids extracted from different organic materials varied between 27.8 and $67.1 \mathrm{~g} \mathrm{Kg}^{-1}$.

\section{Oxygen content, $\mathrm{C} / \mathrm{O}$ and $\mathrm{O} / \mathrm{H}$ ratios}

Oxygen $(\mathrm{O})$ content ranged between 320 and $400 \mathrm{~g} \mathrm{Kg}^{-1}$ in the extracted humic acids (HA) samples. The highest content found in extracted HA from compost sample. Such results indicated that humic acid originated from the compost sample and obtained more oxidized function groups as compared with those originated from the other different humic acids 
Table 2. Elementary composition of humic acid extracted from different samples

\begin{tabular}{|c|c|c|c|c|c|c|c|c|c|c|c|c|}
\hline Sample & $\begin{array}{c}\mathrm{C} \\
\mathrm{g} \mathrm{Kg}^{-1}\end{array}$ & $\begin{array}{c}\mathbf{N} \\
\mathrm{g} \mathrm{Kg}^{-1}\end{array}$ & $\underset{\mathrm{g} \mathrm{Kg}^{-1}}{\mathbf{H}}$ & $\begin{array}{c}\mathbf{O} \\
\mathbf{g ~ K g}^{-1}\end{array}$ & $\underset{\mathrm{g} \mathrm{Kg}^{-1}}{\mathbf{S}}$ & $\begin{array}{l}\mathrm{C} / \mathrm{N} \\
\text { ratio }\end{array}$ & $\begin{array}{c}\mathrm{C} / \mathrm{H} \\
\text { ratio }\end{array}$ & $\begin{array}{c}\mathrm{C} / \mathrm{O} \\
\text { ratio }\end{array}$ & $\begin{array}{c}\mathrm{O} / \mathrm{H} \\
\text { ratio }\end{array}$ & $\begin{array}{l}\mathrm{N} / \mathrm{H} \\
\text { ratio }\end{array}$ & $(\mathbf{N}+\mathbf{O}) / \mathbf{C}$ & $\overline{\mathbf{E}_{4} / \mathbf{E}_{6}}$ \\
\hline Town refuse & 531 & 67.5 & 66.0 & 335 & - & 7.87 & 8.05 & 1.58 & 5.08 & 1.02 & 0.76 & 5.01 \\
\hline Compost & 497 & 52.6 & 50.3 & 400 & - & 9.44 & 9.88 & 1.24 & 7.96 & 1.05 & 0.91 & 6.73 \\
\hline Sewage sludge & 541 & 68.1 & 63.3 & 320 & 7.60 & 7.94 & 8.54 & 1.69 & 5.06 & 1.08 & 0.72 & 4.81 \\
\hline Biogas manure & 536 & 38.0 & 59.7 & 366 & - & 14.1 & 8.98 & 1.47 & 6.13 & 0.64 & 0.75 & 4.68 \\
\hline
\end{tabular}

$\mathrm{C} / \mathrm{H}:$ Atomic ratio of carbon to hydrogen

$\mathrm{C} / \mathrm{O}$ : Atomic ratio of carbon to oxygen

$\mathrm{C} / \mathrm{N}$ : Atomic ratio of carbon to nitrogen

$(\mathrm{N}+\mathrm{O}) / \mathrm{C}$ : Atomic ratio of sum of nitrogen and oxygen to carbon

$\mathrm{E}_{4} / \mathrm{E}_{6}$ of humic acids is the ratio of the absorbance at $465 \mathrm{~nm}$ to that at $665 \mathrm{~nm}$.

residual. This is could be attributed to the increase with time in the oxygenated functional groups $(\mathrm{COOH}$, phenolic $\mathrm{OH}$, alcoholic $\mathrm{OH}$ and methoxyl groups). The lowest content of oxygen (O) was found in HA extracted from sewage sludge and town refuse. Similar result was obtained by El-Ghozoli (1998) who found that the total oxygen content of humic acids extracted from organic residues, generally fluctuated between 320 and 335 .

The lowest $\mathrm{C} / \mathrm{O}$ ratio was found in humic acid originated from compost and biogas manure. Such trend could be attributed to the relatively lower carbon content simultaneously with higher oxygen content of humic acids derived from compost and biogas manure. Also, the variations through the $\mathrm{O} / \mathrm{H}$ ratio of humic acids derived from different treatments are relatively small and ranged between 5.06 and 7.96.

\section{Sulfur Content and N/H Ratio}

Results presented in Tables 2 clear that sulfur content in humic acid ranged between 0 and 7.6 $\mathrm{g} \mathrm{Kg}^{-1}$. Results revealed that the $\mathrm{N} / \mathrm{H}$ ratio of humic acids ranged between 0.64 and 1.08. The highest $\mathrm{N} / \mathrm{H}$ ratio was observed with humic acids derived from sewage sludge followed by that derived from compost. The lowest one was observed with humic acid derived from biogas manure. Such results could be due to relatively higher in nitrogen content combined with lower $\mathrm{H}$ content of humic acids derived from town refuse, compost and sewage sludge.
Results in Table 2 show that the polarity index $(\mathrm{N}+\mathrm{O}) / \mathrm{C}$ of humic acids was ranged between 0.72 and 0.91 . The highest polarity index $(\mathrm{N}+\mathrm{O}) / \mathrm{C}$ was recorded with HA derived from compost, while the lowest one was observed with HA derived from sewage sludge. Similar results were obtained with (Chen et al., 2015). Also, polarity index decreased with increasing sorption. Wang et al. (1997) explained that sorption increases with increasing number of carboxyl groups per molecule and acidity of carboxyl groups. Furthermore, the binding of carboxyl groups in organic matter to clay mineral surfaces is generally strong due to complexation with surface metals (Kubicki et al., 1999), thus the sorption is barely reversible (Avena and Koopal, 1998). In this study, the HA fraction rich in carboxylic functionality may bind to clay surface through ligand exchange with the surface hydroxyl groups or through carboxylate bridging with $\mathrm{Al}$ ions present on the edge surfaces by electron donor-acceptor mechanism. Weber et al. (1992) suggested that $\mathrm{N}$ value can be taken as an index of site energy distribution, i.e. the smaller the $\mathrm{N}$, the more heterogeneous the sorption sites. Therefore, the early extracted $\mathrm{HA}$ fractions with small $\mathrm{N}$ values may have a more heterogeneous structure or composition than the later ones with high $\mathrm{N}$ values. As a chemical mixture can be separated into each individual component or be purified to a relatively homogeneous mixture by solvent extraction, HA after several times of extraction may have a more homogeneous chemical composition. 
In addition, the ratio of E4/E6 of $\mathrm{HA}$ is the ratio of the absorption at $465 \mathrm{~nm}$ to that at 665 $\mathrm{nm}$ has been used for the characterization of humic compounds derived from different organic materials. It is indicative of the degree of condensation of the aromatic nucleus in humic acid (Riffaldi et al., 1983). Added thatE4/E6 data provided further evidence of the heterogeneity of HA progressively extracted from the organic materials, consistent with the elemental composition. Generally, E4/E6 ratio is highly related to the humification degree (decomposition of organic matter) and molecular weight of OM. Results in Table 2 show that E4/E6 ratios was relative high in HA derived in compost (6.73) followed by HA from town refuse (5.01) and sewage sludge (4.81); the lowest ratio was found in biogas (4.68). This results are in agreement with those obtained by Kononova (1966) who reported that $\mathrm{E} 4 / \mathrm{E} 6$ ratios ranging between 3.0 and 7.0 for humic acids.

\section{Total Acidity and Acidic Groups of Humic Acids}

The sum of the dissociable hydrogen of $\mathrm{COOH}$ and phenolic- $\mathrm{OH}$ groups in humic acids samples of both aromatic and aliphatic origins was defined by Schnitzer and Gupta (1965) as total acidity.

\section{Humic acids percentage}

Results in Table 3 report that the percentage of humic acids in different types of organic materials varied from 7.20 to 20.8 , depending on the type of four organic materials used. The results of HA percent in both biogas and town refuse are converging which recorded 20.8 and 20.0 , respectively. The inferior of humic acids percentage $(7.20 \%)$ was recorded in HA from sewage sludge sample.

\section{Total acidity of humic acids}

Results in Tables 3 represent the amount of total acidity of humic acids of the four tested organic materials. The total acidity of the extracted humic acids from the organic materials ranged between 733 and $1233 \mathrm{me} \mathrm{g}^{-1}$ humic acids.

Results found that the highest value of total acidity (1233 $\mathrm{me} \mathrm{g}^{-1}$ ) was found with humic acid extracted from sewage sludge, while the lowest one (733 $\left.\mathrm{me} \mathrm{g}^{-1}\right)$ was observed with HA extracted from biogas. Such results are in agreement with those obtained by El-Ghozoli (1998).

\section{Carboxyl (COOH), Phenolic-OH Groups and Their Ratio in Humic Acids}

Humic acids contain a variety of reactive functional groups such as carboxylic, phenolic, amine and thio groups that can react with the complex of metals. The values of $\mathrm{COOH}$ and phenolic-OH groups of humic acids extracted from the four organic materials were presented in Table 3. The values of carboxylic groups of humic acids extracted from the tested organic materials were higher than the values of phenolic-OH groups. Regarding values of carboxyl groups, results in Table 3 show that the highest value ( $860 \mathrm{me} \mathrm{g}^{-1} \mathrm{HA}$ ) was observed with humic acid derived from town refuse, while the lowest value (560 me $\mathrm{g}^{-1} \mathrm{HA}$ ) was recorded with humic acid extracted from biogas. The corresponding values of phenolic-OH groups were 433 and 106 $\mathrm{me}^{-1} \mathrm{HA}$ for humic acid extracted from sewage sludge and town refuse, respectively.

Moreover, results in Table 3 also show that $\mathrm{COOH} /$ phenolic-OH groups ratios ranged between 1.85 and 8.10 in humic acids extracted from organic materials. The different ratios of $\mathrm{COOH} /$ phenolic-OH were relatively big. This may be due to the low differences between the values of $\mathrm{COOH}$ group in organic materials of different origins. Generally, the differences in the content of total $\mathrm{COOH}$ groups and total phenolic-OH groups could be related to the chemical composition of organic residues as well as the effect of humification processes (Rivero et al., 1998).

\section{Infrared Spectra}

Infrared spectral analysis provides further useful information concerning the molecular structures and characteristic bonds Sakellariadou (2006). Results in Fig. 1 and Table 4,were in agreement with the results of Madejová (2003) and Garcia-Gomez et al. (2005) which reported that the absorption bands could be interpreted as the following: (a) the $3400 \mathrm{~cm}^{-1}$ band is the one where a strong absorption due to hydrogen bonding hydroxyl groups occurs (-OH stretch from-COOH and -OH) like that in Qin et al. (2015); (b) the 2920 and $2860 \mathrm{~cm}^{-1}$ absorption bands are attributed to the asymmetric and 
Table 3. Functional groups and total acidity of humic acids ( $\left.\mathrm{me}^{-1} \mathrm{HA}\right)$ extracted from different organic materials

\begin{tabular}{lccccc}
\hline Organic material & $\begin{array}{c}\text { Humic acids } \\
\text { percentage }\end{array}$ & $\begin{array}{c}\text { Total } \\
\text { acidity }\end{array}$ & $\begin{array}{c}\text { Total } \\
\text { Carboxyl groups }\end{array}$ & $\begin{array}{c}\text { Total phenolic Carboxyl/phenol } \\
\text { groups }\end{array}$ & \\
\hline Town refuse & 20.0 & 966 & 860 & 106 & 8.10 \\
Compost & 14.4 & 766 & 630 & 136 & 4.60 \\
Sewage sludge & 7.20 & 1233 & 800 & 433 & 1.85 \\
Biogas manure & 20.8 & 733 & 560 & 173 & 3.20 \\
\hline
\end{tabular}

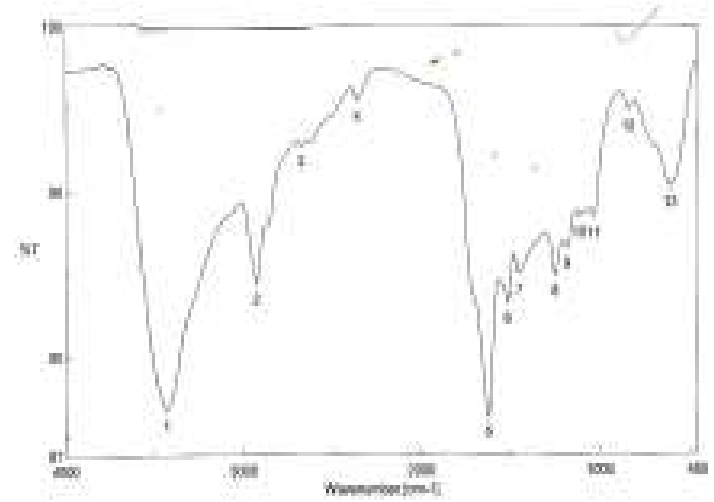

Town refuse

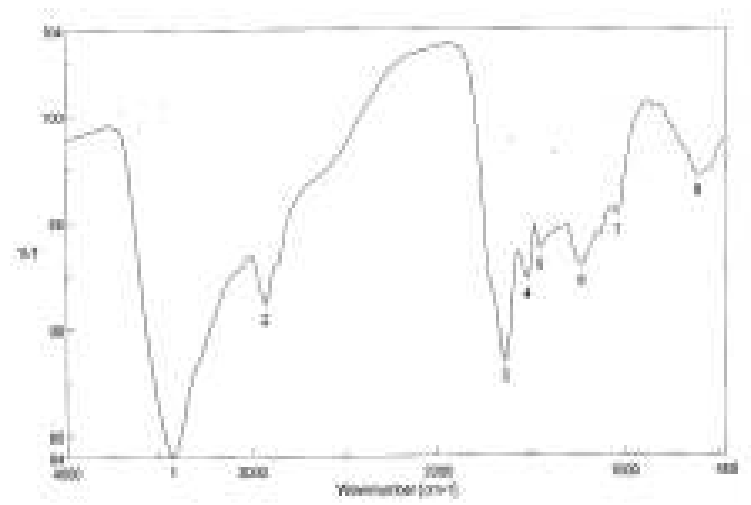

Sewage sludge

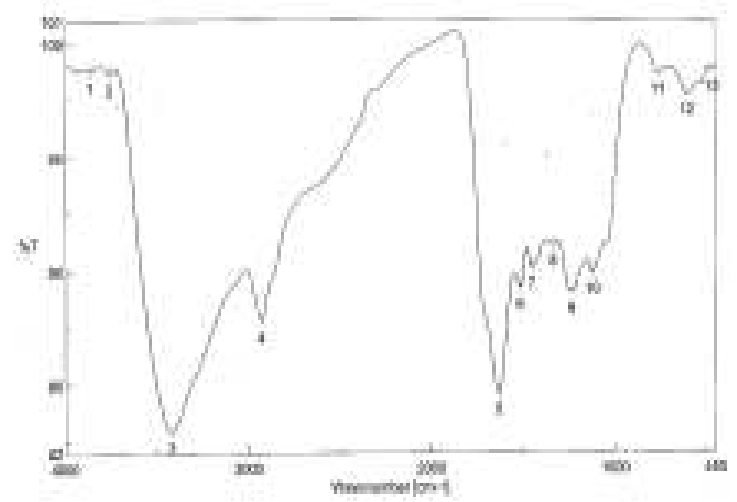

Compost

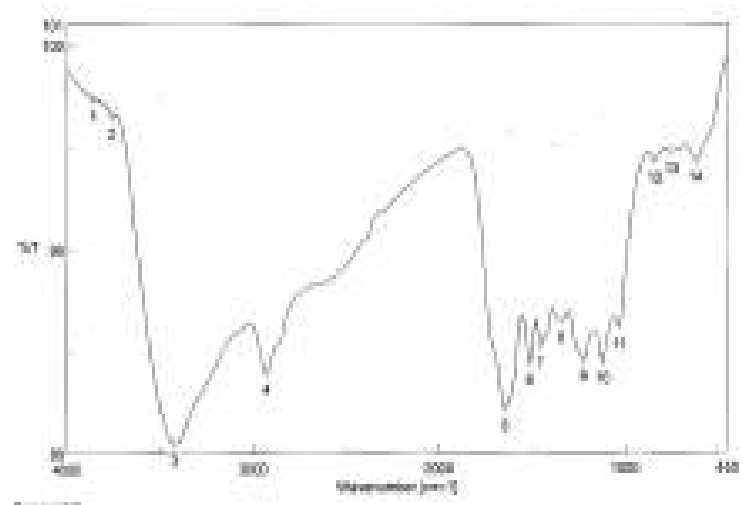

Biogas

Fig. 1. The infrared spectra of humic acids extracted from the four tested organic materials 
Zagazig J. Agric. Res., Vol. 46 No. (3) 2019

Table 4. The main bands present in infrared spectra of four different humic acid samples

\begin{tabular}{|c|c|}
\hline Wave number $\left(\mathrm{cm}^{-1}\right)$ & Functional groups \\
\hline $3300-3500$ & $-\mathrm{OH}$ stretch from $-\mathrm{COOH}$ and $-\mathrm{COH}$ \\
\hline 2800-3100 & $-\mathrm{CH}$ stretch from $-\mathrm{CH},-\mathrm{CH}_{2}$ and $-\mathrm{CH}_{3}$ groups of aliphatic chains \\
\hline $1600-1650$ & $\begin{array}{l}\text { aromatic }-\mathrm{C}=\mathrm{C} \text { vibration; }-\mathrm{C}=0 \text { stretch from } \mathrm{H} \text {-bonded conjugated ketones; } \\
\mathrm{COO} \text { - asymmetric stretch }\end{array}$ \\
\hline 1510-1550 & $\begin{array}{l}\text { aromatic }-\mathrm{C}=\mathrm{C} \text { stretch and/or } \mathrm{N}-\mathrm{H} \text { deformation and } \mathrm{C}=\mathrm{N} \text { stretch from } \\
\text { secondary amides }\end{array}$ \\
\hline 1380-1400 & $\begin{array}{l}-\mathrm{OH} \text { and }-\mathrm{CO} \text { deformation from alcoholic and phenolic - } \mathrm{OH} \text {; - } \mathrm{COO}- \\
\text { symmetric stretch }\end{array}$ \\
\hline $1200-1260$ & $-\mathrm{CO}$ stretch and $-\mathrm{OH}$ bending from $-\mathrm{COOH}$ \\
\hline 1020-1100 & -CO stretch of polysaccharides; $\mathrm{Si}$ - Ostretch from silicate impurities \\
\hline
\end{tabular}

symmetric stretching vibrations, respectively, of aliphatic C-H bonds in methyl and/or methylene units; (c) the band at $1710 \mathrm{~cm}^{-1}$, which in terrestrial humic acids appears as a deep shoulder, is assigned to $\mathrm{C}=\mathrm{O}$ stretch of carboxyl and carbonyl groups; $(\mathrm{d})$ the $1600-1650 \mathrm{~cm}^{-1}$ band is assigned to aromatic $\mathrm{C}=\mathrm{C}$ double bonds conjugated with $\mathrm{C}=\mathrm{O}$ and/or $\mathrm{COO}-$; (e) the absorption at $1540 \mathrm{~cm}-1$ is the amide band due to peptidic linkages; (f) the band at $1385 \mathrm{~cm}^{-1}$ is assigned at $\mathrm{O}-\mathrm{H}$ deformation and $\mathrm{C}-\mathrm{O}-$ stretch of phenols, COO-group vibrations, $\mathrm{C}-\mathrm{H}$ deformation of $\mathrm{CH} 3$; (g) the absorption around $1220 \mathrm{~cm}^{-1}$ is assigned to the $\mathrm{C}-\mathrm{O}$ stretching vibration and $\mathrm{OH}$ bending deformations, due mainly to carboxyl groups; (h.) an intense band around $1035 \mathrm{~cm}^{-1}$ is assigned to alcoholic and polysaccharide $\mathrm{CO}$ stretch and $\mathrm{OH}$ deformation and, eventually, Si$\mathrm{OH}$ bend in silicate impurities. In the present study, the IR spectra show that significant bands occur. The IR absorption characteristics resemble each other significantly, while the relative intensities of specific bands vary. Thus, through a thorough study of the IR spectra, it appears that all samples showed characteristic peaks for the following: hydroxyl, methyl, methylene, aromatic bond, carbonyl, carboxyl, phenol, alcohol, polysaccharide and silicate impurities. While in this study it found that the sample sewage sludge is devoid of -OH and -CO deformation from alcoholic and phenolic - $\mathrm{OH}$; COO- symmetric stretch.

\section{Scanning Electron Microscopy (SEM)}

In general, all HA samples analyzed are rich in carbon and oxygen. SEM can be useful to bring out the fine differences among HA extracted from various sources. SEM photo (Fig. 2) show some crystal-like forms aggregate along with various shapes; these results elucidated that the molecular structure of HA samples varies as per the origin and environment where decomposition has occurred. Fig. 2 shows the granular structure of various HA that have been extracted from the four different organic sources. This characteristic promotes a high metal adsorption (Xu et al., 2006). The metals in this fraction can form bridges with carboxyl groups, interact by chemisorption with oxidized $\mathrm{C}$ groups and form coordination compounds (Pandey et al., 2000) with other functional groups of humic acids, such as hydroxyl, phenol, and methoxy functional groups. Compacted micro aggregates were found in the samples; however, the aggregate size of the biogas (Fig. 2) was greater than those of the other fractions. Changlung et al. (2007) reported that the aggregation phenomenon is important to the transport of metal ions in natural environments. Zhang et al. (2009b) reported that humic acids in dilute solutions form thin thread and net-like structures that grow into larger rings and sheets with increasing humic and cation concentrations. 
694
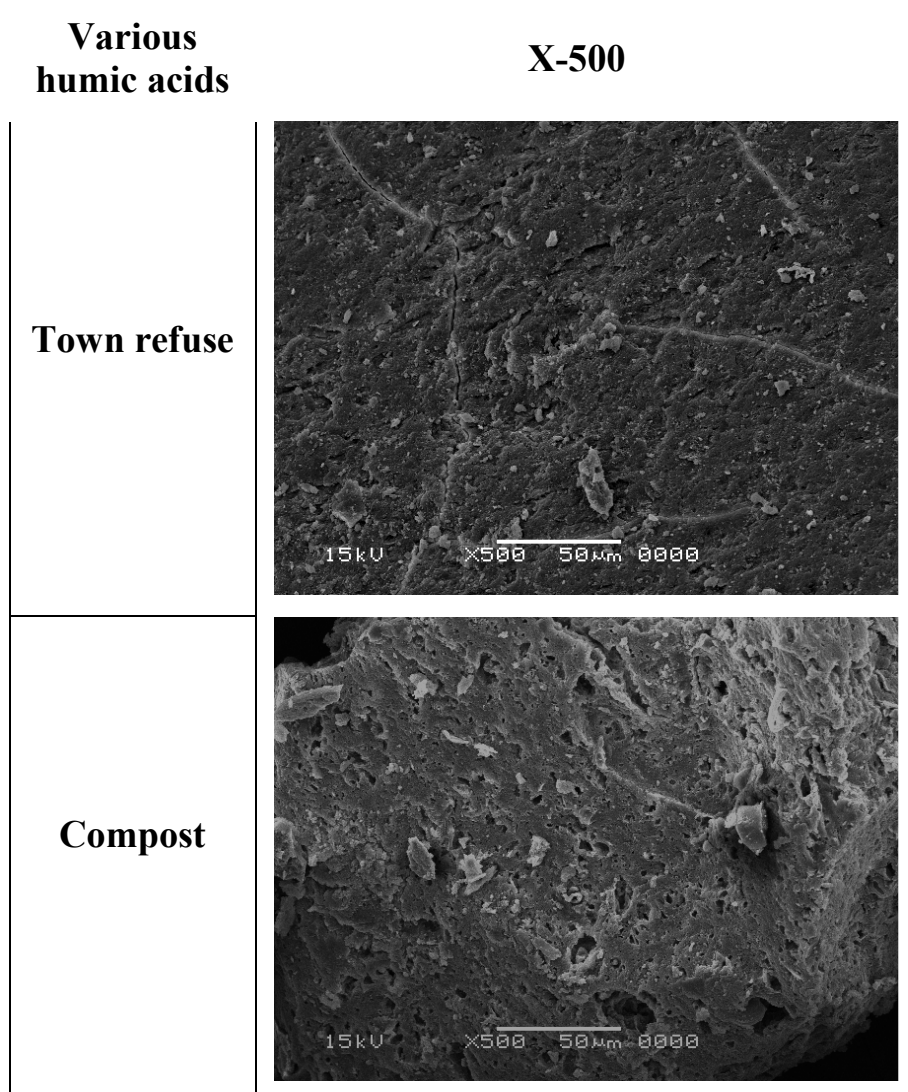

\begin{tabular}{|c|}
\hline \\
Sewage \\
sludge \\
\end{tabular}

Biogas
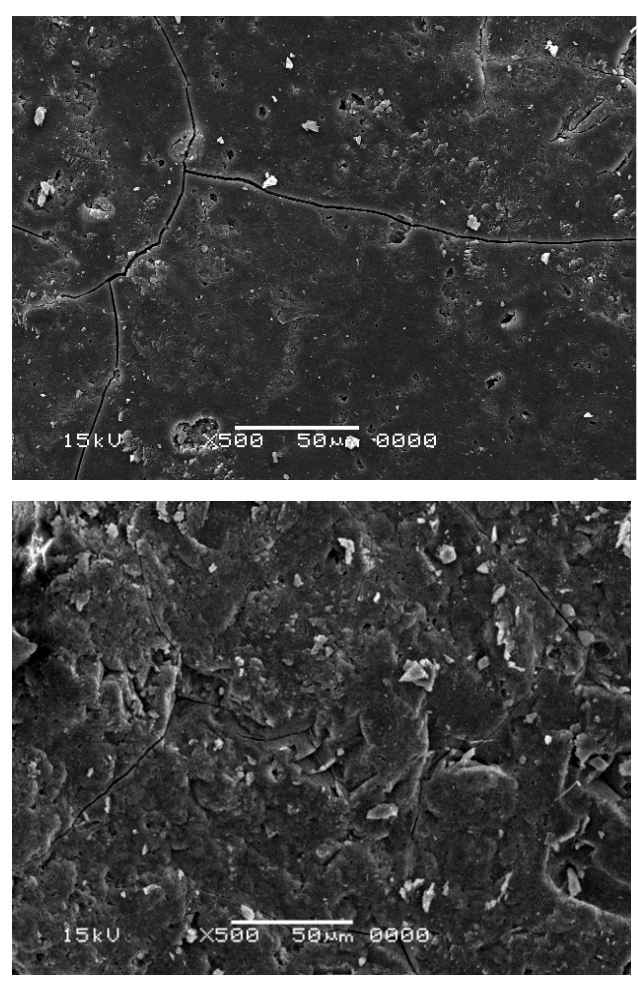

X-2000
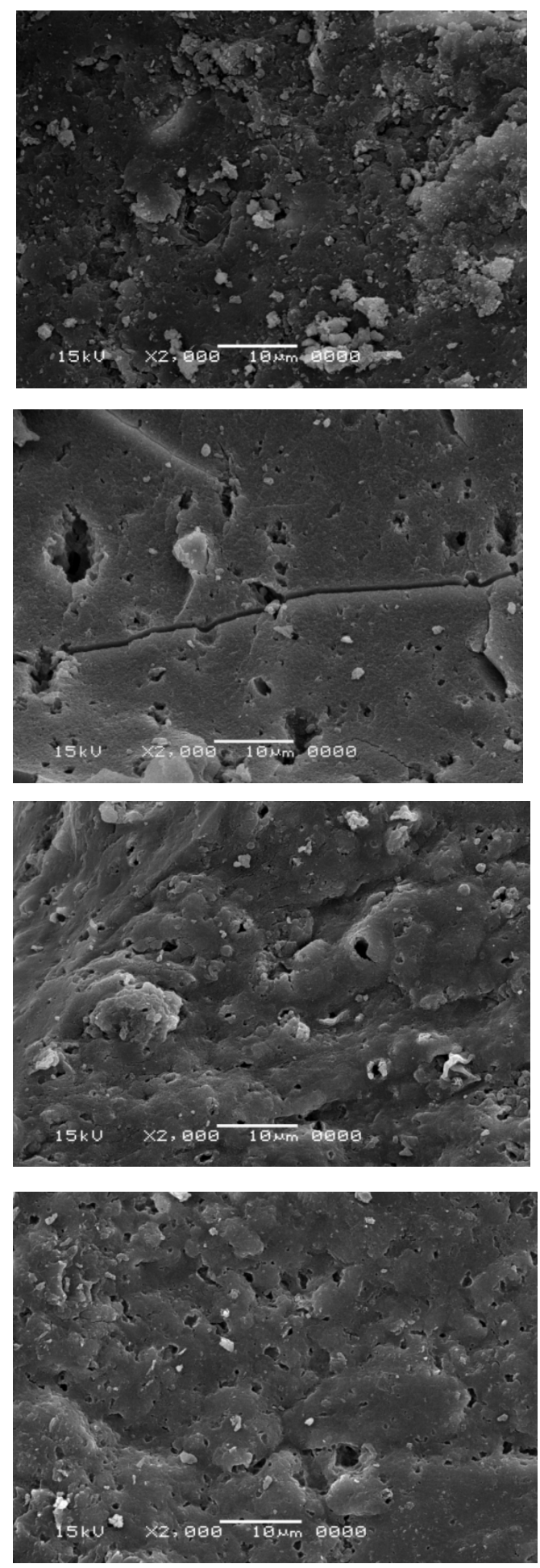

Fig. 2. The granular structure of HA samples from SEM at X-500 and X-2000 


\section{Conclusion}

Humic acids extracted from different organic materials usually used for many purposes. Hence, analyses of these materials by various techniques should be done. In this study results showed that HA exhibit different elemental compositions and spectroscopic characteristics. In general, all HA samples analyses were rich in carbon and oxygen and poor in nitrogen except sewage sludge. This study showed that the chemical composition and active groups of humic acids vary according to the sources which extracted from them, so different techniques must be used to determine their properties.

\section{REFERENCES}

Allam, E.H. (2005). Studies on recycling of some agricultural environment wastes for organic fertilizers production. $\mathrm{Ph}$ D. Thesis, Fac. Agric., Moshtohor, Banha Branch, Zagazig Univ., Egypt.

Avena, M.J. and L.K. Koopal (1998). Desorption of humic acids from an iron oxide surface. Environ. Sci. Technol., 32: 2572-2577.

Baddi, G.A., M. Hafidi, G. Merlina and J.C. Revel (2003). Characterization and identification of polyphones during waste treatment of olive oil mills by composting. Agrochimica Pisa, 47: 161-172.

Changlung, C., X. Wang, H. Jiang and E. Hu (2007). Direct observation of macromolecular structures of humic acid by AFM and SEM. Colloids Surf A., 302: 121-125.

Chen, C.P., W.J. Zhou and D.H. Lin (2015). Sorption characteristics of $\mathrm{N}$ nitrosodimethyl amine onto biochar from aqueous solution, Bioresour. Technol., 179: 359-366.

Cottenie, A., M. Verloo, M. Velghe and R. Camerlynck (1982). Chemical Analysis of Plant and Soil. Laboratory of Analytical and Agrochemistry State Univ., Ghent. Belgium.

Davies, G. and E.A. Ghabbour (1999). Humic substances: structures, properties and uses. J. Ame. Chem. Soc., 12:12215-12216.

El-Ghozoli, M.A.M. (1994). Differentiated effect of different organic residues on soil phosphorus availability. M.Sc. Thesis, Fac. Agric., Moshtohor, Zagazig Univ., Egypt.

El-Ghozoli, M.A.M. (1998). Studies on some organic residues enriched with some macro and micro nutrients. Ph. D. Thesis, Fac. Agric., Moshtohor, Zagazig Univ., Egypt.

Fathi, H., A.H. Zangane, H. Fathi and H. Moradi (2014). Municipal solid waste characterization and it is assessment for potential compost production: A case study in Zanjan City, Iran. Ame. J. Agric. and Forestry, 2, 39-44. http://dx.doi.org/10.11648/j.ajaf. 20140202.14

Ge, B., D. McCartney and J. Zeb (2006). Compost environmental protection standards in Canada. J. Environ. Eng. Sci., 5: 221-234.

Garcia-Gomez, A., M.P. Bernal and A. Roig (2005). Organic matter fractions involved in degradation and humification processes during composting. Compost Sci. and Utilization, 13: 127-135.

Hernández, S.C., A. Gutiérrez, J.M. Galindo, D. González-Weller, C. Rubio, C. Revert, A. Burgos and A. Hardisson (2017). Heavy metal content in sewage sludge: a management strategy for an ocean island. Rev. Salud Ambient, 17: 3-9.

Huerta-Pujol, O., M. Soliva, F.X. MartinezFarre, J. Valero and M. Lopez (2010). Bulk density determination as a simple and complementary too in composting process control. Bioresour. Technol., 101: 995- 1001.

Jackson, M.L. (1973).Soil Chemical Analysis. Advanced course Ed.2.A Manual of Methods Useful for Instruction and Research in Soil Chemistry Physical Chemistry of Soil, Soil Fertility and Soil Genesis. Revised from original Edition 1955, Englewood Cliffs, New Jersey, USA.

Kononova, M.M. (1966). Soil Organic Matter. Pergmon press, oxford, London, Edinburgh, New York, 544.

Kubicki, J.D., L.M. Schroeter, M.J. Itoh, B.N. Nguyen and S.E. Apitz (1999). Attenuated total reflectance Fourier-transform infrared spectroscopy of carboxylic acids adsorbed onto mineral surfaces. Geochim. Cosmochim. Acta, 63: 2709-2725. 
Madejová, J. (2003). FTIR techniques in clay mineral studies, Vib. Spectrosc, 31: 1-10.

Mangricha, A.S., M.A. Loboa, C. B. Tanckb, F. Wypycha, E.B.S. Toledoc and E. Guimarãesd (2000). Criterious preparation and characterization of earthworm-composts in view of animal waste recycling. Part I. correlation between chemical, thermal and FTIR spectroscopic analyses of four humic acids from earthworm-composted animal manure. J. Braz. Chem. Soc., 11: 164-169.

Meinelt, T., K. Schreckenbach, K. Knopf, A. Wienke, A. Stüber and C.E.W. Steinberg (2004). Humic substances affect physiological condition and sex ratio of swordtail (Xiphophorus helleri Heckel.). Aquat Sci., 66: 239-245.

Page, A.I., M. Milner and D.R. Kenny (1982). Methods of Soil Analysis. Part 2: Chemical and Mineral Properties $2^{\text {nd }}$ Ed., Ame. Soc. Of Agron. Series 9, SSA. Madison, Wisconsin, USA, 53711.

Pandey, A.K., S.D. Pandey and V. Misra (2000). Stability constants of metal humic acid complexes and its role in environmental detoxification. Ecotoxicol Environ Saf., 47: 195-200.

Pawlowski, B., J. Krawczyk and P. Bala (2013). The premature deterioration of zinc-coated steel pipes in water distribution system. Int. J. Mater. Mech. Eng., 2: 43-47.

Qin, Z.H., H. Chen, Y.J. Yan, C.S. Li, L.M. Rong and X.Q. Yang (2015). Structural analysis of functional group and mechanism investigation of caking property of coking coal. Fuel Process. Technol., 133: 14-19.

Richards, L.A. (Ed). (1954). Diagnosis and improvement of saline and alkaline soils Agriculture Handbook Washington, DC: US. Depart. Agric. 60, 69-82.

Riffaldi, R., R. Levi-Minzi and A. Saviozzi (1983). Humic fractions of organic wastes, Agric. Ecosyst. Environ., 10: 353-359.

Rivero, C., J. Paolini, N. Senesi and V. Diorazio (1998). Chemical and spectroscopic characterization of humic acids from a soil top sequence in Venezuela. Commun. Soil Sci. Plant Anal., 29: 2893 - 2904.

Sadeghi, S., M. Dehvari, P. Bahmani, P. Teymouri, A. Fattahi, M. Sadeghnia and R.A. Fallahzadeh (2015). Physical-chemical analysis and comparison with standards of the compost produced in Sanandaj, Iran. Open Access Library J., 2: 1855. http://dx. doi.org/10.4236/oalib.1101855

Sakellariadou, F. (2006). Spectroscopic studies of humic acids from subsurface sediment samples collected across the Aegean Sea. Mediterranean Marine Sci., 7 (2): 11-17.

Schnitzer, M. (1975). Chemical, Spectroscopic and Thermal Methods for the Classification and Charactarization of Humic Substances. Pp. 293-310.In: D. Povoledo and H.L. Golterman (eds.), Humic Substances: Their Structure and Function in the Biosphere. Cent. Agric. Publishing and Documentation, Wageningen.

Schnitzer, M. (1977). Recent findings on the characterization of humic substances extracted from soils from widely different climatic zones in soil organic matter studies. Int. Atomic Energy Agency, Vienna, 11: 117- 132.

Schnitzer, M. and U.C. Gupta (1965). Determination of acidity in soil organic matter. In: Soil Organic Matter. (Eds. Schnitzer, M. and Khan, S.U.), Soil Sci. Soc. Ame. Proc., 29: 274 - 277.

Schnitzer, M. and S.U. Khan (1972). Humic substances in the environment. marcel Dekker, New York.

Schnitzer, M. and S.U. Khan (1978). Soil Organic Matter. Elsevier, Amsterdam, the Netherlands, 307.

Schnitzer, M. and S.I.M. Skinner (1968).Alkali versus acid extraction of organic matter, 6 : 105.

Sefidkar, E., M.A. Kazemi, B. Mohebbrad and A. Sadeghi (2013). Chemical analysis of the compost produced in Mashhad city and comparison with standards. J. North Khorasan Univ. Med. Sci., 5: 775-782. 
Siuris, A. (2011). Properties of sewage sludge resulted from urban wastewater treatment in the republic of moldova. UASVM Bucharest, Series A, Vol. LIV, ISSN 1222-5339.

Vomocil, J.A. (1965). Methods of Soil Analysis. Part I, (Ed. Black, CA), Ame. Soc. Agric., 9: $299-314$.

Wang, L.L., Y.P. Chin and S.J. Traina (1997). Adsorption of (poly) maleic acid and an aquatic fulvic acid by goethite. Geochim. Cosmochim. Acta, 61: 5313-5324.

Weber, J.W., P.M. McGinley and L.E. Katz (1992). A distributed reactivity model for sorption by soils and sediments. 1 . Conceptual basis and equilibrium assessments. Environ. Sci. Technol., 26: 1955 - 1962.

Wright, J.R. and M. Schnitzer (1959). Oxygencontaining functional groups in the organic matter of a podzol soil. Nature, Land, 184: 1462-1463.

$\mathrm{Xu}, \mathrm{D} ., \mathrm{S}$. Zhu, H. Chen and F. Li (2006). Structural characterization of humic acids isolated from typical soils in China and their adsorption characteristics to phenanthrene. Colloids Surf a, 276:1-7.

Zhang, C.A., Y.Q. Wang, C.B. Yuan, L. Yao and Y. Liu (2009a). Analysis on the difference of nutrition contents between different anaerobic fermentation residues from different raw materials. Modern Agric. Sci., 1: 44-46. (In Chinese with English abstract).

Zhang, J., J. Dai, R. Wang, F. Li and W. Wang (2009b). Adsorption and desorption of divalent mercury $\left(\mathrm{Hg}^{2+}\right)$ on humic acids and fulvic acids extracted from typical soils in China. Colloids Surf a, 335:194-201.

Zucconi, F. and M. De Bertoldi (1987). Compost specifications for the production and characterization of compost from municipal solid waste. In:" Compost: Production, Quality and Use" (Eds. de Bertoldi, M.; Ferranti, M.P.; L'Hermite, P.and Zucconi, F.), Elsevier, Barking, pp. 30-50. 


\section{خصـائص بعض مصادر المواد العضوية وتحليل حامض الهيـوميـــ المستخلص منها}

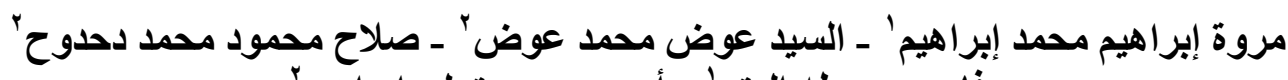

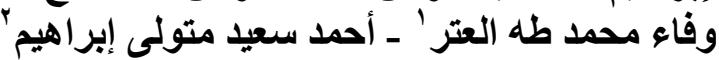

$$
\begin{aligned}
& \text { 1 ـ معهد بحوث الأراضى و المياه والبيئة ـ مركز البحوث الزراعية ـ الجيزة ـ مصر }
\end{aligned}
$$

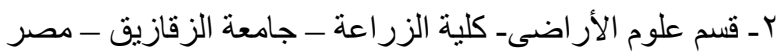

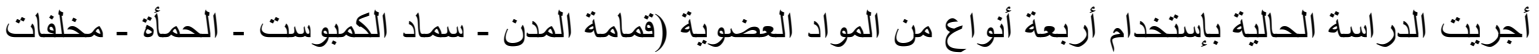

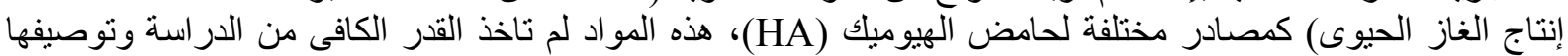

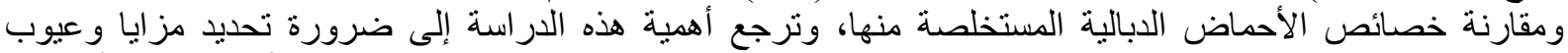

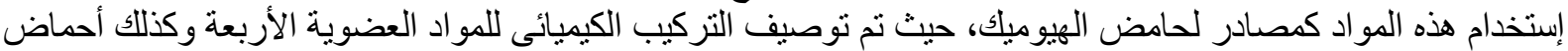

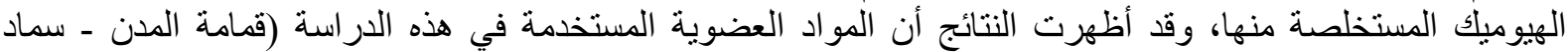

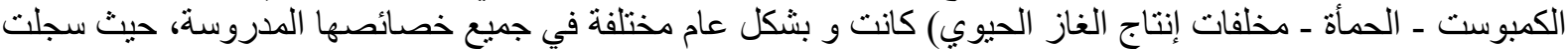

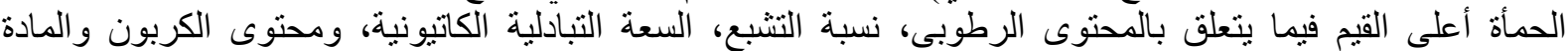

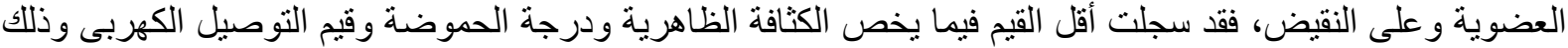

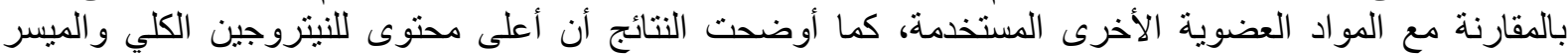

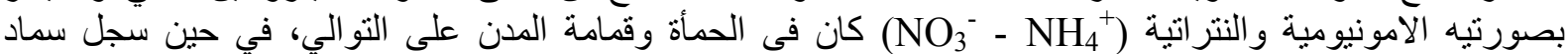

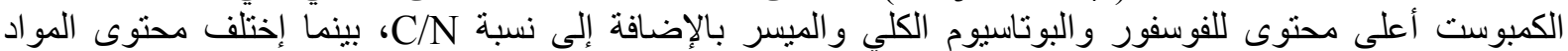

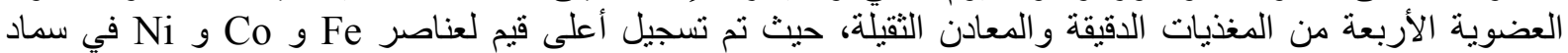

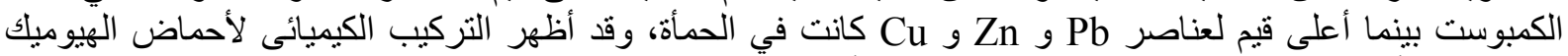

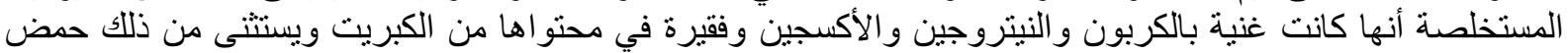

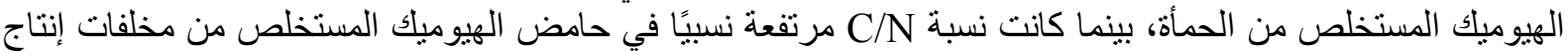

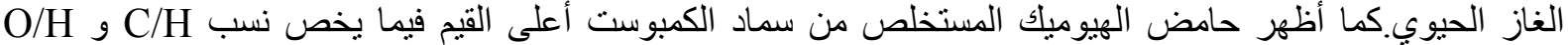
و N+O/C و E4/E6، وقد لوحظ أن أنق أنل قيمة لنسبة N/H كانت في حمض الهيوميك المستخلص من مخلفات إنتاج الغاز

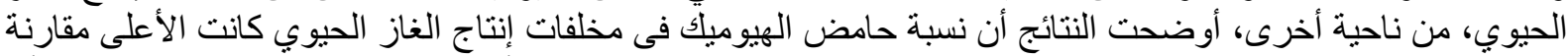

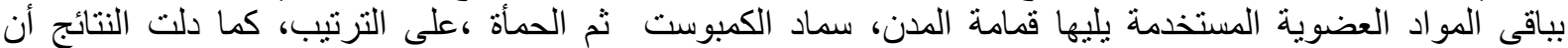

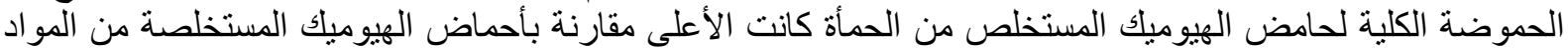

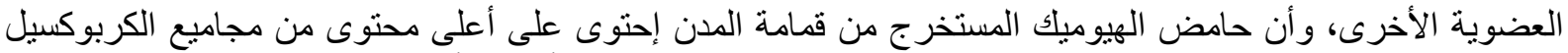

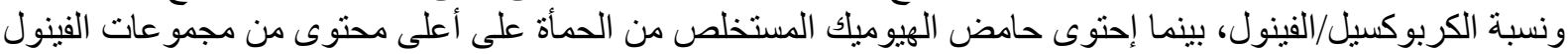

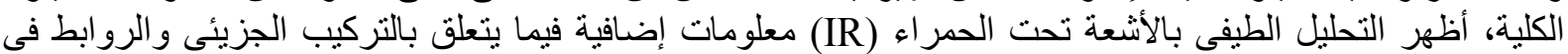

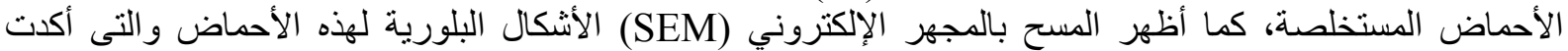

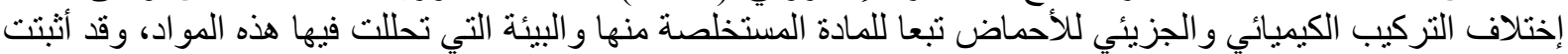
الدراسة الحالية أن التقنيات الطيفية والتصويرية يمكن استخدامها بنجاح لإظهار الاختلافات بين أحماض الهيات الهيوميك المستخلصة من مصادر عضوية مختلفة. 